

\title{
Doing Europe: Agency and the European Union in the field of counter- piracy practice ${ }^{1}$
}

\author{
Christian Bueger
}

Cardiff University, School of Law and Politics, Museums Avenue, Cardiff CF103AX, Wales, UK, email: buegercm@cardiff.ac.uk

The practice turn provides new avenues for core questions of international relations and European Studies. This article draws on a practice theoretical account to shed new light on the constitution of agency in global politics. An understanding of agency as achievement that requires significant practical work and the participation in international fields of practice is developed. Drawing on the case of the field of counter-piracy practice and the EU' s work to counter piracyoff the coast of Somalia it is shown how the EU achieved the position as a core actor in the field. A detailed discussion of the EU' s workin interrupting and knowing piracy, in building capacity and in governing piracy is provided.

Keywords: Practice theory; agency; European Union; Somali piracy; international fields;

\section{Introduction: Practice and Agency}

Whether the EU is an actor on the global stages in its own right has been a much debated issue in European Studies. Most of this research remains preoccupied with elaborating the complex institutional thicket of the EU and its foreign policy, or with delivering thick descriptions of either debates in Europe or case studies of the small range of CSDP missions. The strongest contenders of theorizing European agency and leaving behind 'realist pessimism' -rejecting European actorness - 'institutionalism', or 'mission descriptivism' are so far discourse theoretical positions (Diez 1999, Diez 2001; Jorgensen 2013). Their focus is on the discursive construction of European agency, or "speaking Europe" as Diez (1999) has programmatically put it. In this article I investigate what understanding of European agency can be developed from a practice theoretical perspective. Practice theory, a research program that centers on practices as the smallest unit of analysis has become widely utilised in International Relations research (Adler and Pouliot 2011; Bueger and Gadinger 2014); increasingly it also informs the study of the EU (Adler-Nissen 2015; Bichci and Bremberg, in print). It presents a major new set of ideas through which core questions in the study of Europe and international relations can be addressed differently.

Contributing to this agenda of studying Europe through practice theoretical lenses, my objective is to elaborate on a core claim of practice theory, namely that agency does not exist prior or outside of practice. Agency is a property of practice. This implies to understand agency as a relational achievement. To understand how actorhood is achieved we need to investigate the efforts of participating in practices. In consequence, the core question of this article is how does the EU participate in international fields of practice and how is thereby a specific form of agency produced or done?

Since theorizing practice in the absence of actual practices doesn' $t$ make much sense I draw on the case of a distinct field of practice. My case is the field of counter-piracy practice. I study the efforts of the EU in the fight against Somali piracy starting from 2008. Counter-piracy offers a particularly exciting

\footnotetext{
1 Research for this article has benefitted from a grant by the Economic and Social Research Council [ES/K008358/1]. I am grateful to Niklas Bremberg, Federica Bicchi, the anonymous reviewers of European Security the participants of the workshops in Stockholm and London where earlier versions of the paper were presented and to Kerstin Tomiak for research support. The data on which this article draws could not have been gathered without the help of a range of interlocutors active in counter-piracy, which shall remain anonymous. I am grateful for their support.
} 
case. It has become an interesting playing field for international actors including the EU. ${ }^{2}$ As a field of practice, counter-piracy is characterized by experimentation: international actors have introduced and tried out a range of new means and ways of cooperating with each other. It is a field of international activity that is relatively novel and characterized by high complexity. It was only from 2008, when piracy attacks off the coast of Somalia started to escalate that it became an issue that international political actors paid attention to, and in consequence started to initiate activities to fight piracy. Given this novelty, no existing international institution could make a legitimate claim to have authority over the issue; given the complexity of the issue no agency was able to deal with it on its own. When the field of counter-piracy evolved, roles and responsibilities were hence undefined, and no routines of addressing piracy were settled. With these characteristics, and in contrast to long established and institutionalized fields, counter-piracy provided an issue area in which roles, authority and responsibilities had to be negotiated. This in turn provided particular space for the participation of emergent international actors, such as the EU. Moreover, the field of counter-piracy was from the beginning characterized by a strong convergence. Counter-piracy actors agree on a common problem definition in legal, territorial, and politics terms. In consequence, the field is less characterized by rivalries, clashing interests, or competition. For European states there was a strong convergences of national agendas - whether these are general concerns over the safety of trade (e.g. Germany, France, UK), the shipping industry (Denmark, Greece, UK), the fishing industry (France, Spain) or over the stability of the Eastern African region and Somalia in more general terms (France, Italy, UK).

As I demonstrate in the following, throughout the evolution of the counter-piracy field the EU increasingly performed a leadership role and moved from the periphery to the centre. Gradually the EU became a lead actor in all of the major counter-piracy practices.. With the launch of EUNAVFOR Atalanta in 2009, the EU became one of the "big three" military providers and vital in maritime situational awareness. Through programmes, such as the MARSIC, or EUCAP Nestor projects, the EU became one of the core agencies in capacity building. When the European External Action Service (EEAS) assumed in 2014 the chairmanship of the Contact Group on Piracy off the Coast of Somalia (CGPCS) - the central site of governance in the counter-piracy field -the EU also became a core diplomatic and governance actor in the field.

In recasting the journey of the EU from the periphery to the center, my objective is hence both theoretical - to further investigate how practice theory can shed light on fundamental questions of IR theory - and empirical - to describe and understand the EU' $s$ rde in the fight against Somali piracy. The discussion draws on data and observations gathered in a wider praxiography of counter-piracy governance. ${ }^{3}$ The primary interest of this praxiography was in describing and understanding the practices by which the international community responds to Somali piracy.

I start in offering a brief discussion of my assumptions and concepts. This clarification is important since my understanding of what follows from centring theory in practice differs from other variants of the family of practice theories. I start out from a strong relationalist position on practices. The discussion of actual practices, that is, how the EU participated in counter-piracy practice, shall however receive center stage. I discuss Europe' s contribution tothe four practices that constitute the field: 1) interruption practices, 2) epistemic practices, 3) capacity building practices, and 4) governing practices. In the conclusion I intend to scale up and come back to the implications of my empirical discussion for European Studies and the debate on international agency.

\footnotetext{
${ }^{2}$ Compare the discussion in Bueger 2013a, and 2014b: 82-84.

${ }^{3}$ For the notion of praxiography see Bueger (2014a). The term aims at grasping the actual study of practices, in contrast to the notion of "practice theories". As briefly elaborated below, it hence emphasizes the importance of descriptive work and hence prioritizes close observation of what actually goes on, over a theory of fictitious forces. The article primarily draws on the results of different research techniques including meeting observations, conversations with counter-piracy actors, as well as the analysis of recorded interviews, documents and a range of other artefacts.
} 


\section{Practice}

Practice theories have become a strong contender in the repertoire of international relations theory. They promise new insights by starting out investigations of global politics from the study of practices (Adler and Pouliot 2011; Adler-Nissen 2015, Bueger and Gadinger 2014). The primacy of practice implies that explanations for social and political order are not sought in the inter-subjective coordination of (interest-driven or norm-following) individuals, but in shared understandings, that is culture. Culture in turn is not understood as based in human minds or in discoursive structures, but in practical activities (Reckwitz 2002). The majority of practice theories conceive of practices as 'embodied, materially mediated arrays of human activity centrally organized around shared practical understandings' (Schatzki 2001:2). A widespread conceptualization of practices sees them as composed of relations between three core elements: bodily movements, material artefacts and shared practical understandings (Reckwitz 2002, Bueger 2014a:387). Much philosophical ink has been spelled on how to define these elements and their relations. Various conceptual apparatuses have been worked out - of which perhaps Bourdieusan praxeology, Wenger' s communities of practice approachand Actor-Network Theory are the most well-known. This has led to a quite heterogeneous family of practice theories (Bueger and Gadinger 2014). Here I follow an understanding of practice theory which mainly appreciates it as an empirical project of describing and deciphering practices. As I have argued elsewhere, such a project can be best described as praxiography (Bueger 2014a), that is, as an account that conceives of 'theory' as a set of sensitizing concepts useful for empirical analysis. This understanding follows many of the ideas as they are discussed under the label of Actor-Network Theory elaborated by, among others, Bruno Latour, John Law or Annemarie Mol (see Bueger and Gadinger 2014: 43-50).

The move from practice theory' $s$ concern about identifying general and systematic patterns to praxiography implies that rather than searching for general abstractions, "we have to attend carefully to practices and ask how they work' (Law 2012: 157). In consequence, if we want to understand how Europe is done on an international stage, and how international agency is produced we need to peer to specific sites and their practices. Investigating the sites of counter-piracy and their practices, does not lead us to general conclusions of how Europe is performed in world politics, but provides insights into how such practices work. Such practices are highly context dependent, and hence might be fundamentally different if one investigates other sites. Saying that we need to proceed empirically does not imply that we can survive without a parsimonious set of basic assumptions and sensitizing concepts. I here follow the lead of John Law, that "practices are detectable and somewhat ordered sets of materialsemiotic relations' (Law 2012: 157). As Law (2012: 157) describes it,

'to study practices is [...] to undertake the analytical and empirical task of exploring possible patterns of relations, and how it is that these get assembled in particular locations. [...] Realities, objects, subjects, materials, and meanings, whatever form they take these are all explored as an effect of the relations that are assembling and doing them. Practices, then, are assemblages of relations.'

Practices form together a distinct activity system and are geared at achieving a specific effect. They centre on the production of an 'object of activity' Objects of activity might relate to a certain state or object, such as an epistemic object (Knorr Cetina 2001), or a "matter of concern" (Latour 2004), that is, a distinct problematic issue or situation. A useful research strategy for praxiography is hence to explore practice by identifying an object of activity that these practices produce or aim at coping with. The practices I discuss in the following have a common object, they are directed at stopping piracy off the coast of Somalia. These practices shall be described by the term ' counterpiracy practice' .

Practices do not have definite scale. While they are patterns and relations, they do not exist in a natural scale. In consequence we can zoom in and zoom out as it makes analytical sense. With the term 'field of practice' , I like to describe a bundle of pactices, that is, a distinct practical configuration consisting of several practices which together achieve effects. I take the global field of counter-piracy practice to be such a configuration. As has been argued elsewhere ${ }^{4}$, and as further elaborated below, the field consists of a set of four practices which each address the object of Somali piracy. Yet, each of the four

\footnotetext{
${ }^{4}$ For a detailed discussion of each of these practices and in how far the global field is composed of them see Bueger and Stockbruegger 2013 and Bueger 2013a.
} 
practices take a different direction and purpose: Interruption practices are concerned about stopping piracy activities. They are composed of various patterns of activity and include the surveillance of the operational terrain of pirates, patrolling these areas, interrupting piracy attempts, arresting pirates, collecting evidence and prosecuting them. Epistemic practices are concerned with knowing piracy. This includes the maintenance of the collection and circulation of data on piracy, studying the organization of piracy, and making threat assessments and trends analyses. Capacity building practices are concerned with building the capacity in the piracy infested region to stop and prevent piracy in the future. Various activities can be clustered around this notion, including law drafting, mentoring, training courses, or exercises. Governing practices involve scripting, orchestrating and aligning practices so they pursue a common interest. Activities such as coordination meetings, negotiating the text of communiques or drafting reports belong to this cluster. These four practices should not be seen in isolation from each other. It is their relations that forms together the field of counter-piracy practice. They form functional parts, none of them could be reduced to the other and there is no clear hierarchy between them.

Within the practice theoretical ontology, actors are an effect of relations. Actors are made in and through these relations and in the way they enact certain practices. The primary status of actors is as participants in practices; they enact practices; they might simply reproduce them, or re-invent them. In consequence we need to start out with getting a sense of what the practices are that drive a distinct field before we go to the question of how actors contribute or play in it. As Passoth, Peuker and Schillmeier (2012: 5) remark, such a position is based on, "the twist not to begin with a definitive answer concerning what agency is, but to look at the diverse situations from where different forms of agency emerge".

In consequence, to gather insights about EU actorness on the global stage the practice theoretical perspective poses the following research question: How does the EU participate in international fields of practice, such as the field of counter-piracy practice?

\section{The Field of Counter-Piracy Practice}

Fields of practice are constituted by patterns of practices geared at an object of activity. The field of counter-piracy practice started to substantially form in 2008 when (Somali) piracy was recognized as a problem requiring international action. The UN Security Council held its first debate on piracy in that year and UN sanctioned naval action was initiated. In earlier years, piracy was an issue debated frequently within the Maritime Safety Committee of the International Maritime Organization (IMO). This led to a range of recommendations, in particular for shipping companies, but not to immediate actions. In 2008 the IMO decided to send a request to the United Nations Security Council to deal with the matter. Piracy is an issue on the agenda of the council since; a series of resolutions authorize international action, and the UN Secretary-General reports on the issue bi-annually. To coordinate those governments affected by piracy or active in addressing it, in spring 2009 the Contact Group on Piracy off the Coast of Somalia (CGPCS) was established. ${ }^{5}$ Initially only a limited forum, participation in it grew quickly to over 60 states, international organizations, and non-governmental organizations. The CGPCS meets bi-annually to discuss the state of counter-piracy and coordinate activities. Very quickly it became the institution at the centre of the emerging field, since it provided the forum in which all actors engaged in counter-piracy would meet. Other core institutions of the field include the Shared Awareness and Deconfliction mechanism, known as SHADE, likewise initiated in 2009. SHADE is an informal forum in which the naval forces active in counter-piracy meet quarterly to inform each other about their plans and intentions and to organize joint operations, such as group transits or surveillance. This brief review of core sites and actors already gives an impression of the extensive relations that the field of counter-piracy practice established since its initial formation.

Observing what happens at these sites gives us clues about the set of practices that can be described as governing practices. Governing practices are activities that are concerned about the coordination of actions, maintaining their relations, and developing shared narratives that describe the problem,

\footnotetext{
${ }^{5}$ For a discussion of the CGPCS see Tardy (2014).
} 
measures to its solutions, and the activities and roles of the diverse actors. "In such practices the relation and sharing of labour between organizations is negotiated and norms, rules and standards for the counter-piracy field are developed" (Bueger 2013a: 96). To a large degree this set of practices is structured or informed by the routines of diplomatic practices (Pouliot and Cornut 2015) and legal practices (Latour 2010).

To understand the other practices of the counter-piracy field, we have to scrutinize the substantial issues discussed in the field' sfora, and peer to the actual actions taken in the region of concern. This leads us, firstly, to actions that are concerned with stopping piracy activities. These can be clustered around the notion of interruption practices. These practices involve a combination of military, policing and judicial activities. ${ }^{6}$ The UN Security Council in the first instance mandated naval action and starting from 2009 all major international navies operate in the Horn of Africa and the wider Western Indian Ocean region with a counter-piracy mandate. Navies patrol the area, engage in surveillance, offer specific protection schemes for shipping vessels, and aim at interrupting piracy attempts and arresting suspects. Piracy suspects are then transferred to regional states, where they are prosecuted and potentially jailed.

The next set of practices are activities which are directed at improving the capacities of littoral states to prevent and handle piracy incidents. Capacity building practices are concerned with building the capacity in the piracy infested region to stop and prevent piracy in the future. These are informed by the repertoire of development assistance and statebuilding practices (Graef 2015). A 2009 assessment report by the CGPCS revealed the low capacities of littoral states to provide basic maritime security and prosecute and jail pirates. ${ }^{7}$ In reaction a substantial number of capacity building projects was launched. These initially focussed on rule of law projects and ensuring human rights in prosecuting states, such as Kenya. They were increasingly broadened to also build maritime security capacities, such as coast guards or navies. Various activities can be clustered around this practice. It includes support for prisons, courts, maritime authorities, police units, coast guards or navies by sending mentors, organizing training courses and exercises, providing offices and equipment.

The final set of practices that drive the field of counter-piracy practice, is perhaps the least obvious, that is epistemic practices. Any field of practice, and any governance activity draws on an episteme, that is, a certain set of knowledge, assumptions and facts. Epistemic practices are concerned about making piracy known and creating the (epistemic) object which is the object of activity (Bueger 2015). This implies to collect data about piracy behaviour and organizational structures, but also to hypothesize the origins and causes of piracy and what can be done against it. Practices that produce or distribute knowledge about piracy were instrumental to the field from its onset (Bueger 2015). In particular incident reports and statistics documented the drastic increase in piracy activity in 2008. In later stages, once the counter-piracy measures showed success, piracy knowledge allowed to focus efforts and evaluate the success of operations.

It is important to recognize that these four sets of practices are streams of activities. They are not stable or fixed institutions, but processes. They change. Participants in the practices have throughout the evolution of the field adjusted and transformed them, and included new elements. Understanding counter-piracy as a field of practice hence emphasizes that we are not confronted with a stable and clearly expressed regime or institutional architecture, but with a moving and changing arrangement. If counter-piracy draws on and integrates formal institutions and processes, it is in essence a field that depends on, often informal, activities. This fragile and contingent character of the field is not the least observable through the recurrent changes of practices and the position of actors in enacting them. In the next step of analysis, I shall document how the position of the EU has been changing throughout the life span of the field and how the EU achieved to become a central counter-piracy actor. I discuss the contribution of the EU to the enactment of the four central counter-piracy practices.I start with the EU' $s$ role in interruption as the domain in which it engaged first. I proceed in showing how it gradually became active in the other practices, that is epistemic and capacity building practices, as well as most recently in the domain of governing practices.

\footnotetext{
${ }^{6}$ See the overview given in the chapters of Guilfoyle (2013).

${ }^{7}$ See Houben (2014).
} 


\section{Interruption Practices: One of the ' Big Three'}

When the UN Security Council mandated states in 2008 to engage in military activity to contain Somali piracy, a range of European naval vessels was already employed in the region with a counter-terrorism mandate. Several of them had already encountered pirates. With international plans crystallizing to organize naval counter-piracy operations, the EU announced it could take over the protection of shipping in the area. The EU' s first reaction in 2008 was to establish a naval coordination cell (EUNAVCO). Operating from Brussels the cell was intended to coordinate the national naval activities of member states (EU Doc 2008/749/CFSP). Quickly these plans were changed and the launch of an integrated European and Security Defence mission was prepared. Hence, in November 2008 European Union Naval Force (EUNAVOR) Somalia Operation Atalanta was established by a decision of the Council (EU Doc 2008/851/CFSP). The first naval European Security and Defense mission ever, was declared to be operational in December of the same year. To get fully operational, however, took longer than expected and the EU was only ready to start in spring 2009. NATO had to step in with its mission Operation Allied Provider. NATO' s operation was inilially about to end once the EU was ready. It was however continued when it became clear that the EU NAVFOR in its own would be insufficient. Hence NATO's Operation Ocean Shield was launched.

The EU installed a naval headquarter and a situational awareness room in the UK' s naval headquarters in Northwood the same compound which also hosts NATO' s operational naval headquarters.A network of political liaison officers - so called POLAD' s, "political advisors" was established across the Western Indian Ocean region. These were tasked to handle local logistics and deal with the relations to the countries which provide ports or prosecute pirates (including e.g. Djibouti, Kenya, or the Seychelles). A logo for the mission was created which depicts Somalia as well as a naval vessel. The mission has a significant public affairs dimension. A dedicated website was created under the address eunvafor.eu which provides information on the mission, such as the mandate or force structure, as well as pictures from the day to day activities. A dedicated Public Affairs Office started to publish a weekly newsletter on the mission and offered regular media support. Together with the mission a Facebook page was launched, which started to show significant activities from 2013 when the Public Affairs Office started to provide daily updates and pictures on the mission.

As Germond and Smith (2009) have argued, Operation Atalanta represents a significant milestone in the European Security and Defence policy. This concerns at least three areas, firstly, the way that Atalanta relies on joint planning, a joint headquarters, and the pooling of resources, that goes far beyond the low scale coordination of prior ESDP missions. Secondly, as Germond and Smith suggest, in contrast to other missions, Atalanta relied on a shared strategy and a European definition of threats and interests. 'Atalanta thus clearly represents the EU' s first ESDP operaton that directly serves EU member states' interests (by protecting their maritme trade)' (Germond and Smith 2009:576). 'The EU decision to launch Atalanta was clearly motivated by common perceptions of not just the interests but also the grandeur of the EU and the affirmation of its values' (Germond and Smith 2009:583). Thirdly, with Atalanta the EU acted for the first time as an independent international security actor. It was the first mission that 'did not involve or require the use of NATO resources, including its planning capacities or operational headquarters' (Germond and Smith 2009:576). As suggested by Gebhard and Smith (2014) the operation also allowed to meet NATO at the same height and to develop and explore new means of informal cooperation between the organizations.

The mission was scheduled to last for an initial period of twelve months (until December 2009). It was subsequently extended by the Council of the EU for three years (until December 2012), then for two further years (until December 2014), and most currently until December 2016 which is the projected end date of the mission. The missions mandate is a rather peculiar one since it projects the operation as a primarily humanitarian one centred on the protection and guarantee of safe delivery of humanitarian aid to Somalia by the World Food Program. Framing the mission in such terms camouflaged the main purpose of it, that is, to protect merchant vessels and interrupt piracy activities (Bueger 2010). Yet, such a framing not only ensured national political support for the mission and parliamentary endorsement (Peters, Wagner and Glahn 2014; Riddervold 2011). It also allowed the EU to present the mission as a 
full success from the onset, despite the growth in piracy activity between 2009 and 2011. The mandate has gone nonetheless through several substantial operational changes. In July 2010, the area of operation was extended from 500 nautical miles off the Somali coast to the entire Indian Ocean reflecting the growing operational terrain of pirates. In May 2011, it was decided by the Political and Security Committee (PSC) that navies should also take action against motherships. In March 2012, the operational terrain was further extended in that it now included the destruction of pirate infrastructure (ships, supplies, etc.) on Somali coastal terrain.

Atalanta became soon known as one of the so called 'big three'. The big three became the colloquial term among counter-piracy practitioners to refer to the three main operations (NATO' s Ocean Shield and the US-led Combined Maritime Task Force 151 being the other two). As a sort of triumvirate, the big three initiated a range of operational coordination measures. This included the SHADE mechanism in which all navies active in counter-piracy coordinate their operations. SHADE was initially chaired in a rotation between the big three. An International Recommended Transport Corridor (IRTC), a high protection area for shipping in which the deployment of naval assets is coordinated, was introduced. Part of Atalanta was also to install an information sharing and communication centre (the Maritime Security Centre Horn of Africa based in Bahrain), which was, as further discussed in the following section, designed to provide maritime situational awareness, and incident and activity alerts, as well as to handle the communication with the shipping industry. The EU also initiated an internet-based communication platform, called MERCURY, which provides a real-time chat enabled infrastructure for coordinating the activities between naval actors.

In the realm of interruption practices, the EU very quickly assumed the role of a leading participant. Following a slow start, it recognizably shaped how the practice is carried out by participating in the planning and implementation of measures such as the IRTC, SHADE as well as by installing MERCURY. Indeed the EU gained the status of one of the "big three" along with established security organizations such as NATO.

\section{Epistemic Practices: A Fuzzy Profile}

Before the launch of counter-piracy operations from 2008, epistemic activities were primarily carried out in the frame of the reporting mechanisms of the International Maritime Organization and the International Maritime Bureau of the International Chamber of Shipping, both of which continued to be major knowledge producers after 2008. With the rise of Somali piracy the range of actors participating in epistemic practices, however, continuously expanded. Soon epistemic actors included advocacy organizations, such as the US non-governmental organization Oceans Beyond Piracy, international organizations such as the World Bank, the UN Sanctions Monitoring Group for Somalia, as well as a growing group of academics. Also the naval operations entered this field. They recorded piracy activity through a reporting system, but also implemented large scale surveillance measures,for instance, through reconnaissance planes. The EU participated in the epistemic practices in at least three ways, by organizing a reporting system, by conducting so-called strategic analyses for policymakers, and by developing a counter-piracy strategy. Compared to the domain of interruption practices, the EU has, however, maintained a less visible presence, and its profile as an actor is fuzzier.

The EU set up and runs the Maritime Security Center Horn of Africa (MSCHoA) in Bahrain. Since its inception in 2009, MSCHoA became a core backbone of the reporting of ship movements and the primary point of contact for the international shipping community to report an attack. The so-called Best Management Practices for the shipping community call upon shippers to register with MSCHoA when transiting through the piracy high risk area. Although the main purposes of the organization are in the distribution of knowledge, coordinating military responses and the relation between mariners and navies, MSCHoA is also a primary data collector on piracy incidents. This data feeds into strategic assessments of the big three. The information collected also constitutes the data on which the piracy statistics as based. These statistics are published by EUNAVFOR on its website, but also inform the socalled 'SHADE briefings' . SHADE briefingsare conducted at the CGPCS meetings. They are a main channel by which international policy actors attending the CGPCS meetings are informed about current 
developments. The SHADE briefings are carried out by representatives from the big three in rotation. Hence, through these briefings the EU established authority as a recognized knowledge producer about piracy. If these two forms of participation in epistemic practices (maintaining MSCHoA and conducting briefings) are on the level of producing knowledge about the object of piracy, the strategic document developed by the EU is an example of knowledge production in terms of a response. In 2011 the European Council published its so called Strategic Framework for the Horn of Africa. As discussed by Petretto and Erhart (2014), the framework provided a major attempt to contextualize the fight against piracy in a larger set of policy measures towards rebuilding the Somali state. It provided one of the first documents which suggested that in order to tackle piracy the larger context and the origins of piracy (the so-called root causes) require to be addressed.

In sum, the EU was able to become a core actor in the domain of epistemic practice. In comparison to interruption practices, this profile was, however, less well established. This has to be seen in light of the observation that the overall number of actors in the domain of epistemic practices is significantly larger, and that less attention was paid to promote the role of the EU in this domain.

\section{Capacity Building: Muddling in a Mess}

Early counter-piracy activities concentrated on interruption practices. The overall emphasis in the field, increasingly shifted to capacity building, when from 2012 piracy activities declined. Compared to interruption practices, capacity building is less well organized. A quite messy and uncoordinated range of activities is carried out mainly on a bilateral rather than a multilateral level. Various states and NGOs play in this practice. Two core actors, however, established a clear international profile from 2008:, firstly, the International Maritime Organization and its regional capacity building project, the so-called Djibouti Code of Conduct (DCoC), and, secondly, the United Nations Office of Drugs and Crime (UNODC) Counter Piracy Programme (CPP) primarily working in the police, justice and prison sector. The EU was initially a largely invisible contributor to capacity building. It primarily acted as funder of these project without achieving significant visibility. This fundamentally changed with the launch of a new ESDP mission, EUCAP NESTOR, in 2012. Since then the EU has aimed at becoming the core actor in organizing and maintaining capacity building.

In the early days of counter-piracy, capacity building was concentrated on enabling regional states to handle piracy suspects, organize trials and ensure imprisonment following human rights standards. Initially, this work was primarily carried out by UNODC CPP. The EU funded a significant portion of the CPP but did not act in its own right in this area. UNODC documents carried a small note saying 'funded by the European Union'. Apart from this barely recognizable note, the EU was hardly seen as a capacity builder. The other main project,the IMO' s DCoCentailed setting up a regional information sharing centre and running regular training courses and exercises with representatives of regional states. The EU supported DCoC with the so called MARSIC project which was contracted out to a French consultancy. MARSIC is a project funded under the Instrument for Stability of the Development and Cooperation Directorate General and ran from August 2010 to July 2015 with a 6 million budget. Its core activities were to support DCoC by organizing training and mentoring activities. MARSIC is certainly the least well known EU activities and the IMO was taking the main credentials for the DCoC. By 2010 the low profile of the EU in the domain of capacity building started to be recognized as problematic by EU staff. Plans arouse to promote the EU' s contributionin the area ${ }^{8}$, but also to set up an independent capacity building mission.

With the creation of EUCAP Nestor the EU explicitly aimed at creating an independent profile in the domain of capacity building. The civilian ESDP mission was launched in July 2012 with a mandate of delivering training and providing mentors in Djibouti, Kenya, Somalia, Seychelles and Tanzania EU (Doc 2012/389/CFSP). The objective was to assist these states in "self-sustainable capacity for continued enhancement of their maritime security including counter-piracy, and maritime governance" (EU Doc. 2012/389/CFSP). When Nestor started its work it found a rather difficile environment. For

\footnotetext{
${ }^{8}$ For instance, this issue was constantly flagged during conversations with EU practitioners in Nairobi 2010.
} 
many practitioners and prospective recipients it was unclear how the mission would deliver what was not already being done by the existing capacity building projects. In consequence, Nestor had a rather rocky start. It struggled to identify its niche or to spend its budget and one of the main recipients (Kenya) declined the offered support (House of Commons 2013, Bueger 2013b). With a new head of mission joining the operation, Nestor made significant efforts to step up its activities, but still faced a staffing problem and the difficult security situation in Somalia. In consequence, Nestor primarily was active in two countries: in Djibouti, where also its headquarters was located and in the Seychelles. In both countries an extensive training and mentoring programme was launched. Improving its public image and visibility became increasingly important for the mission. This implied to engage in outreach activities such as a Facebook page, a newsletter, or the organization of a briefing for CGPCS participants during the 2013 CGPCS meeting in Djibouti. After a review of the mission conducted in 2014 it was decided in summer of that year to extend the mission for further 2 years.. The renewed mandate implied that the mission now should focus its efforts on Somalia and also move the headquarters to Mogadishu.

The increasing efforts of the EU, and EUCAP Nestor specifically, to participate in capacity building were also reflected in contributions to the governance of capacity building. As further discussed in the next section, the EU initiated a sub-group of the CGPCS, the Capacity Building Coordination Group to steer capacity building efforts. In 2014 EUCAP Nestor took up the chair of this group. In the field of capacity building practice the EU was hence initially only a shadow player that funded and supported ongoing activities while the glory was taken by others. With the launch of EUCAP Nestor this however changed and the EU has made significant efforts to be recognized as a core player and implementer in this set of practices.

\section{Governing Practices: Moving to the heart of the field}

Governing practices involve scripting, orchestrating and aligning practices so they pursue a common interest. The main site of governing practices is the international contact group, the CGPCS, in which international actors meet to discuss and agree on a strategy. The main actors in governing practices and the CGPCS are clearly states. If other actors, such as representatives of international and regional organizations, companies, NGOs or navies, are participants in the CGPCS, the group is run by state representatives, that is, national delegations composed of professional diplomats. Organized by diplomatic practices, chairmanship over the plenary of the CGPCS and its different working groups was hence in the hand of states. Other actors would only give presentations or updates (such as the SHADE briefing already discussed).

In the early days of counter-piracy the EU did not have a significant voice or role in governing practices, other than through the presentations given by EUNAVFOR as part of SHADE. It was not allowed to take a leading role, but participated as observer. This status incrementally changed when the European External Action Services (EEAS) started to launch the EUCAP Nestor mission. Recognizing that capacity building practice would require more coordination and that EUCAP Nestor would be entering a crowded field, the EEAS proposed a new sub-group to one of the CGPCS working groups. When the Capacity Building Coordination Group (CBCG) was launched as a technical sub-group of one of the working groups, it was a novum, for the first time a body of the CGPCS was not chaired by states. Three international organizations, the EEAS, along with IMO and UNODC took over the chair. After a series of meetings of the group, in 2014 EUCAP Nestor became the chair..

Having successfully proven its capacity to chair a sub-group, in 2013 the EEAS was approached to take over the chairmanship of the entire CGPCS. The EEAS was formally invited to chair by the plenary and it subsequently took over in January 2014. This was again a novum since the CGPCS had only been chaired by states before. As a former chairperson phrased it in a discussion "The EU is doing a lot, so why shouldn' t they take the responsibility and chari?". In 2014 the EEAS organized the CGPCS meetings. The chairmanship implied that the EEAS presided over the actual meetings, designed the meeting agenda, and, most importantly, was leading on the negotiation and drafting of the main output of the group, that is, the communique. Recognizing that chairing an international organization, if only 
an informal one, was significant first for the EU and the EEAS, the EEAS seized this opportunity in significant ways. The chairmanship was taken over by a Deputy Secretary General of the EEAS and supported by a significant team of staff. In January the EEAS organized an informal CGPCS strategy meeting hosted by the EU Institute for Security Studies which launched a reform process of the group. The EEAS organized two plenary meetings of the CGPCS and used both to populate the programme with a significant numbers of presentations of EU missions and bodies. As the EEAS summarized its role in its report: "The Chairmanship of the Contact Group allows the EU to assume international responsibility commensurate with its involvement in the Horn of Africa and Somalia in particular" (EEAS 2014). Having successfully chaired the CGPCS for a year the EEAS started the search for a successor following the established routine of a rotating chairmanship. Since no other candidate stepped up, the EEAS agreed to continue its work and chaired the group for another year. A further plenary meeting was organized by the EEAS. And in autumn 2015 the work was handed over to the government of the Seychelles. During its tenure as chairperson, the EEAS could clearly demonstrate its capacity as an international actor. The significant achievements of the EU, such as leading on the reform process of the group, negotiating a solution to one of the main controversies in the group over the revision of core measures, as well as preparing for what was now called the 'endgame of the fight against piracy', were widely recognized among counter-piracy practitioners.

In the field of governing practices then the EU, represented by the EEAS, worked its way up from a marginal player in the early stages of the field, to achieve the position of the core orchestrator of the field in 2014 and 2015. The fact that, contrary to established diplomatic practice, the EU was invited to chair the CGPCS, demonstrates how successful the overall efforts of taking a leadership role and becoming recognized as a major counter-piracy actor were.

\section{Doing Europe and the Empirical Study of ' Actor-Work'}

The starting point for a praxiographic inquiry on agency is to understand the practices that maintain a distinct socio-political order. In this article, this order was the field of counter-piracy practice- a set of heterogeneous activities to address the international problem of (Somali) piracy. To be an actor implies to enact, to reproduce, shape or re-invent the practices that maintain this order. Agency is not a property of individuals or entities, it is an achievement. It requires work. As I have shown the EU has significantly and increasingly participated in maintaining this order. Through this work the EU achieved the status as one of the pivotal counter-piracy actors. A diverse range of activities was required to achieve and maintain this status. This included sending out navies, managing headquarters, organizing the epistemic flow of piracy knowledge, engaging in capacity building through sending staff and organizing missions, staffing and maintaining offices, organizing meetings or mundane activities such as providing folders for the international community. And it included substantial efforts of presenting the EU as a counter-piracy actor through various public diplomacy measures or offices.

Practice theory and the toolbox of praxiography gives us powerful ways of thinking and researching the question of agency differently. Much of International Relations Theory holds on to an ontology of the international that takes the agency of states for granted and project them as the main actors. Questions of agency usually arise only when other (non-state) actors are at stake, such as the various international and regional organizations or the transnational communities, networks or professions active in international relations. In international organizations research, for instance, there is a long line of investigations of whether these entities are actors in their own right (Barnett and Finnemore 2004). Decades of constructivist scholarship has aimed to show how other entities than states matter (Avant, Finnemore and Sell 2010). Much of this scholarship moves into the right direction when it argues that they matter because they act on the stages of global politics. Yet, there is the constant risk to fall in the trap of defining agency in relation to states, that is, to understand someone as an (autonomous) actor, if the exertion of influence (or an effect) on states can be proven. Understanding agency as acting is also the intent of a practice theoretical account. Yet, there is no reason to grant special status to the state. As has been shown in recent relational scholarship (Passoth and Rowland 2010), the state, likewise, is not a fixed entity, but an achievement. It is an entity that requires ongoing maintenance work and struggles to have agency on the international levels. The practice-theoretical account hence starts out from 
parsimonious premises and turns the question of agency into an empirical puzzle as related to the maintenance of distinct socio-political orders. Practice theory hence first of all invites us to study the work that is required to become an actor. This implies to pays close attention to how practices unfold empirically and to study how they are enacted. For this we require methods that bring us close to the actual activities which is the purpose of the praxiographic toolbox. As has been demonstrated in the discussion, 'actor-work' should be seen in relation to particular fields of international practice. Rather than making absolutist claims about actorhood, determining who is an actor and who not on the basis of theoretical criteria, we are invited to study the work of actorness in relation to particular domains of international activity. This provides us with a much more finegrained and complex picture of who the actors and their identity in international relations are, and allows to appreciate divergence across fields. In short, the practice-theoretical perspective invites us to think and study agency differently. If we are interested in how Europe achieves international agency, than we have to ask how it is done in specific international fields of practice.

\section{References}

Adler, E. and Pouliot, V., eds. 2011. International Practices. Cambridge: Cambridge University Press.

Adler-Nissen, R. 2015. "Towards a Practice Turn in EU Studies: The Everyday of European Integration." JCMS: Journal of Common Market Studies 54 (1), 87-103.

Avant, D., Finnemore, M. and Sell, S.K., eds. 2010. Who Governs the Globe? Cambridge: Cambridge University Press.

Barnett, M. N., and Martha Finnemore, M. 2004. Rules for the World: International Organizations in Global Politics. Ithaca, New York: Cornell University Press.

Bueger, C. and Gadinger. F. 2014. International Practice Theory: New Perspectives, Basingstoke: Palgrave MacMillan.

Bueger, C. and Stockbruegger, J. 2013. Security Communities, Alliances and Macro-securitization: The Practices of Counter-Piracy Governance, in Struett, M.J., Nance, M.T. and Carlson, J.D., Maritime Piracy and the Construction of Global Governance, London: Routledge, 99-124.

Bueger, C.. 2010. Is ATALANTA a Humanitarian Mission? Piracy-Studies.org Blog, November 2010, http://piracy-studies.org/2010/is-atalanta-a-humanitarian-mission/

Bueger, C. 2013a. Responses to Contemporary Piracy: Disentangling the Organizational Field, in Guilfoyle, D., Modern Piracy: Legal Challenges and Responses, Cheltenham: Edward Elgar, 91-114.

Bueger, C. 2013b. In search for a mission? The EU' s regional training mission EUCAP Nestor, Piracy-Studies.org Blog, October 2013, http://piracy-studies.org/2013/in-search-for-amission-the-eus-regional-training-mission-eucap-nestor/

Bueger, C. 2014a. Pathways to Practice. Praxiography and International Politics, European Political Science Review 6(3), 383-406.

Bueger, C. 2014b. Experimental Governance: Can the Lessons of the CGPCS be transferred to other policy fields?, in Tardy, T., The Contact Group on Piracy off the Coast of Somalia (CGPCS). A Lessons Learnt Compendium, Paris: EU Institute for Security Studies, 78-85.

Bueger, C. 2015. Making things known: Epistemic Practice, the United Nations and the Translation of Piracy, International Political Sociology 9(1), 1-18. 
Diez, T. 1999. "Speaking 'Europe' : The Politics of Integtaion Discourse." Journal of European Public Policy 6 (4), 598-613.

Diez, T. 2001. "Europe as Discursive Battleground. Discourse Analysis and European Integration Studies." Cooperation and Conflict 36 (1), 5-38.

Ehrhart, H-G., and KPetretto, K. 2014. "Stabilizing Somalia: Can the EU' s Comprehensive Approach Work?” European Security 23 (2), 179-194.

European External Action Services (EEAS). 2014. EU 2014 Chairmanship Contact Group on Piracy off the Coast of Somalia, available at http://eeas.europa.eu/cfsp/cgpsc/index_en.htm

Gebhard, C., and Smith, S.J. 2014. "The Two Faces of EU-NATO Cooperation: Counter-Piracy Operations off the Somali Coast" Cooperation and Conflict. 50 (1), 107-127

Germond, B., and Smith, M. 2009. "Re-Thinking European Security Interests and the ESDP: Explaining the EU' s AntiPiracy Operation." Contemporary Security Policy 30 (3), 573-593.

Graef, J. 2015. Practicing Post-Liberal Peacebuilding. Legal Empowerment and Emergent Hybridity in Liberia. Basingstoke: Palgrave Macmillan.

Guilfoyle, D., ed. 2013. Modern Piracy. Legal Challenges and Responses. Cheltenham: Edward Elgar.

Houben, M. 2014. Operational coordination of naval operations and capacity building. In Tardy, T., The Contact Group on Piracy off the Coast of Somalia (CGPCS). A Lessons Learnt Compendium, Paris: EU Institute for Security Studies, 28-34.

House of Commons. 2013. European Scrutiny Committee - Eighth Report of Session 2013-14, 22 FCO (35109) The EU and the Horn of Africa, 3 July 2013, London: House of Commons.

Jorgensen, K. E.. 2013. "Discursively (de-)constructing European Foreign Policy: Theoretical and Methodological Challenges." Cooperation and Conflict 50 (4), 492-509.

Knorr Cetina, K. 2001. Objectual Practice, in Schatzki, T.R, Knorr Cetina, K. and von Savigny, E., The Practice Turn in Contemporary Theory, London/New York: Routledge, 175-188.

Latour, B. 2004. "Why Has Critique Run out of Steam? From Matters of Fact to Matters of Concern." Critical Inquiry 30 (2), 225-248.

Latour, B. 2010. The Making of Law. An Ethnography of the Conseil d'Etat. Oxford: Polity Press.

Law, J. 2012. Collateral Realities, in Domingez Rubio, F. and Baert, P., The Politics of Knowledge, Abingdon: Routledge Press. 156-178.

Passoth, J-H., and Rowland, N.J. 2010. Actor-Network State: Integrating Actor-Network Theory and State Theory. International Sociology 25 (6), 818-841.

Passoth, J.-H., Peuker, B. and Schillmeier, M., eds. 2012. Agency Without Actors? New Approaches to Collective Action. London: Routledge.

Peters, D., Wagner, W., and Glahn, C. 2014. Parliamentary Control of CSDP: The Case of the EU' s Fight against Piracy off the Somali Coast. European Security 34 (4), 430-448.

Pouliot, V., and J. Cornut. 2015. Practice Theory and the Study of Diplomacy: A Research Agenda. Cooperation and Conflict 50 (3), 1-19. 
Reckwitz, A. 2002. Toward a Theory of Social Practices: A Development in Culturalist Theorizing. European Journal of Social Theory 5 (2), 243-263.

Riddervold, M. 2011. Finally flexing its muscles? Atalanta - The European Union's naval military operation against piracy, European Security 20(3), 385-404.

Riddervold, M. 2014. New Threats - Different Response: EU and NATO and Somali Piracy. European Security 23 (4), 546-564.

Schatzki, T. R. 2001. Practice Theory, in Schatzki, T.R, Knorr Cetina, K. and von Savigny, E., The Practice Turn in Contemporary Theory,. London/New York: Routledge, 1-14.

Tardy, T., ed. 2014. The Contact Group on Piracy off the Coast of Somalia (CGPCS). A Lessons Learnt Compendium, Paris: EU Institute for Security Studies. 